\title{
A Novel Method for the Determination of Pectinesterase Inhibitor in Banana
}

\author{
YUH TAI WANG ${ }^{1}$, BO-JHIH WU ${ }^{2}$, HUNG-MIN CHANG ${ }^{2}$ AND JAMES SWI-BEA WU ${ }^{2 *}$ \\ 1. Life Science Center, Hsing Wu College, 101, Sec. 1, Fen-Liao Rd., Lin-Kou, Taipei 244, Taiwan, R.O.C. \\ 2. Graduate Institute of Food Science and Technology, National Taiwan University, Taipei 106, Taiwan, R.O.C.
}

(Received: November 13, 2006; Accepted: February 20, 2007)

\begin{abstract}
A novel enzyme-linked immunosorbent assay (ELISA) method for the quantification of pectinesterase inhibitor (PEI) in banana was described. The method was based on the specific binding of PE with PEI, rabbit anti-PE polyclonal antibody and goat antirabbit IgG-conjugated alkaline phosphatase in series. The ELISA method was found to be more sensitive to quantify PEI in banana, jelly fig (Ficus awkeotsang Makino) achene, and kiwi than the conventional pH-stat method. It thus provides a good alternative that saves raw material and efforts in the analysis of PEI in both fresh and processed fruits. The retardation in the ripening of banana pulp in low temperature storage was proven relevant to the maintenance of PEI activity as determined by both methods.
\end{abstract}

Key words: pectinesterase, inhibitor, $\mathrm{pH}$-stat method, ELISA, postharvest

\section{INTRODUCTION}

Pectinesterases (pectin methyl esterases; PEs; E.C. 3.1.1.11) that catalyze the de-esterification and transacylation of homogalacturonic acid units of pectins ${ }^{(1)}$ are ubiquitous enzymes that can be found in plants, microbial pathogens ${ }^{(2)}$ and symbiotic microorganisms during their interactions with plants ${ }^{(3)}$. In plants, PEs play important roles in physiological processes, such as microsporogenesis, pollen growth, seed germination, root development, polarity of leaf growth, stem elongation, fruit ripening and loss of tissue integrity ${ }^{(4-9)}$. The $\mathrm{PE}$ is also required for the systemic spread of tobacco mosaic virus through the plants ${ }^{(10,11)}$.

PEs can be inhibited by KI and Na-dodecyl sulfate $^{(12,13)}$ as well as four kinds of specific inhibitors as follows: 1. some polysaccharides (about $200 \mathrm{kDa}$ ) in potato that are consisted of uronic acids mainly ${ }^{(14)} ; 2$. a glycoprotein from kiwi fruit that displays remarkable inhibition on PEs from tomato, orange, apple, banana and potato sources ${ }^{(15)}$; 3. a thermal stable PE inhibitor (PEI) from jelly fig achenes that is able to reduce the activities of PEs from citrus, jelly fig achenes, tomato, apple, asparagus and guava ${ }^{(16)} ; 4$. an extremely thermostable $(80 \%$ activity retained after $3 \mathrm{hr}$ in boiling water) PEI found in banana, especially the rubbery fruit ${ }^{(17)}$, that acts against banana and pea pod PEs.

Potentially, the most promising application of PEI is to be added to the fresh fruit juice prior to very mild thermal treatment in the production of minimum processed juice at a quality level unachievable by the

\footnotetext{
* Author for correspondence. Tel: +886-2-3366-4117;

Fax: +886-2-2362-0849; E-mail: jsbwu@ntu.edu.tw
}

conventional pasteurization process ${ }^{(18,19)}$. PEI may also be a good additive for winemaking industry to reduce the methanol content in fruit wine ${ }^{(20)}$. Recently, PEI from jelly fig achenes was found to exert a strong inhibition for the growth of human leukemic U937 cells via the following mechanisms: caspase-3 activity upregulating, mitochondria transmembrane potential reduction and apoptosis induction $^{(21)}$.

The conventional assay of PE and PEI activities is to employ a $\mathrm{pH}$-stat to monitor the release of protons from carboxylic acid groups, which is resulted from the PE action on pectin molecules. The sensitivity of the $\mathrm{pH}$-stat method is limited by the sluggishness in $\mathrm{pH}$ change due to the buffer introduced from sample preparation.

PEI from kiwi fruit (Actinidia deliciosa) and PE of tomato (Lycopersicon esculentum) were reported to form a complex in a ratio of $1: 1^{(22-24)}$. Therefore, we assume that the ratio of PE and PEI in a complex in other samples is also constant and propose that the change in free PE content as a result of PEI addition could be taken as a measure of PEI content.

Our aim was to establish a novel ELISA method involving the use of anti-PE polyclonal antibody for the assay of $\mathrm{PE}$ content and to provide a sensitive and precise alternative for PEI determination. Bananas in postharvest storage were taken as the raw material for experiments.

\section{MATERIALS AND METHODS}

\section{Purification of PE from Banana}

PE was purified following the protocols as described 
by Jiang et al. ${ }^{(16)}$ and $\mathrm{Wu}$ et al. ${ }^{(17)}$ with modifications. One kilogram of mature banana fingers (Musa sapientum $L$.; peel color index 3) were peeled, sliced, mixed with $10 \% \mathrm{NaCl}$ in $1: 4(\mathrm{w} / \mathrm{v})$, and homogenized in a chilled Waring blender for 2 min to obtain homogenate of $2 \%$ $\mathrm{NaCl}$. The homogenate was centrifuged at $10,000 \times \mathrm{g}$ for $30 \mathrm{~min}$ and the pellet was discarded. The supernatant was fractionated by $30-70 \%$ saturation of $\left(\mathrm{NH}_{4}\right)_{2} \mathrm{SO}_{4}$, dialyzed overnight against $0.15 \mathrm{M} \mathrm{NaCl} / 10 \mathrm{mM}$ Tris-HCl $(\mathrm{pH} 7.5)$ at $4^{\circ} \mathrm{C}$, and concentrated using a Centriprep ${ }^{\mathrm{TM}}$ concentrator (MWCO $10 \mathrm{kDa}$, Amicon). Subsequently, the concentrate was loaded over a CM-Sepharose CL-6B ion-exchange column $(2.6 \times 40 \mathrm{~cm})$, which was then eluted with $10 \mathrm{mM}$ Tris- $\mathrm{HCl}(\mathrm{pH} 7.5)$ in a $\mathrm{NaCl}$ gradient $(20$ to $800 \mathrm{mM})$, and a Sephacryl S-200 gel filtration column $(1.6 \times 95 \mathrm{~cm})$ in $100 \mathrm{mM}$ Tris- $\mathrm{HCl}(\mathrm{pH} 7.5)$ to collect fractions with PE activity and $280 \mathrm{~nm}$ absorbance. The purified banana PE was used as the antigen for anti-PE polyclonal antibody preparation.

\section{Gel Electrophoresis}

The purified PE was also analyzed by sodium dodecyl sulfate-polyacrylamide gel electrophoresis (SDS-PAGE) on a $12.5 \%$ gel following by Coomassie brilliant blue R-250 staining. The low molecular weight protein markers $(97,66,45,30,20.1$, and $14.4 \mathrm{kDa})$ used in the electrophoresis were purchased from Pharmacia.

\section{Preparation of PEI from Banana, Kiwi and Jelly Fig Achenes}

Crude PEIs from kiwi fruit, jelly fig achenes, and banana pulp were prepared according to the methods described by Giovane et al. ${ }^{(24)}$, Jiang et al. ${ }^{(12)}$, and $\mathrm{Wu}$ et $a l .^{(17)}$, respectively.

\section{Protein Assay}

Protein concentrations in solutions containing PE or PEI were determined using Bio-Rad protein assay dye reagent (Hercules, CA) with bovine serum albumin as the standard.

\section{Determination of PEI by $\mathrm{pH}$-stat Method}

The activity of PEI was determined according to the method described by Jiang et al. ${ }^{(16)}$. In brief, 0.5 $\mathrm{mL}$ of mixture containing crude PEI and citrus PE (1.0 unit $/ \mathrm{mL}$; Sigma), which was incubated previously for 10 min at room temperature, was added into $5 \mathrm{~mL}$ of $0.1 \mathrm{M}$ $\mathrm{NaCl} / 0.5 \%$ citrus fruit pectin (degree of esterification = $68 \%$; Sigma) substrate solution at $30^{\circ} \mathrm{C}(\mathrm{pH} 6.5)$ immediately before assay. The inhibition on the PE-catalyzed formation of free carboxyl groups was evaluated through the titration of the counter ion, $\mathrm{H}^{+}$, using an autotitrator ( $\mathrm{pH}$ M83 Autocal pH meter, TTT 80 titrator, ABU 80 autoburette; Radiometer, Copenhagen, Denmark), and taken as a measure of PEI activity. The volume of 0.01 $\mathrm{M} \mathrm{NaOH}$ needed to maintain the $\mathrm{pH}$ of 6.0 of the reaction solution at $30^{\circ} \mathrm{C}$ for 5 min was recorded. One PEI activity unit represents one $\mu$ equiv reduction of free carboxyl group production in the pectin substrate per minute.

\section{Preparation of Anti-PE Polyclonal Antibody}

Anti-PE polyclonal antibody was prepared by immunizing New Zealand white male rabbits intramuscularly with the purified banana PE as described by Tsai and Cousin ${ }^{(25)}$.

\section{Determination of PEI by ELISA Method}

A sandwich ELISA protocol was applied by referring to Tsai and Cousin ${ }^{(25)}$ and Buchta ${ }^{(26)}$ with modifications. Briefly, $50 \mu \mathrm{g}$ PEI in $100 \mu \mathrm{L}$ coating buffer was immobilized overnight on the surface of a 96-well polystyrene microplate at $4{ }^{\circ} \mathrm{C}$. Each coated well was washed four times each with $200 \mu \mathrm{L}$ phosphate-buffered saline (PBS) containing $0.05 \%$ Tween 20 (Tween-PBS), blocked with $100 \mu \mathrm{L}$ of $2 \%$ gelatin-PBS at $37^{\circ} \mathrm{C}$ for $30 \mathrm{~min}$, and rinsed with Tween-PBS. Each rinsed well was added with $100 \mu \mathrm{L}$ of purified banana PE in coating buffer, incubated at $4^{\circ} \mathrm{C}$ overnight, and blocked with $100 \mu \mathrm{L}$ of $0.5 \%$ gelatin-PBS at $37^{\circ} \mathrm{C}$ for $30 \mathrm{~min}$. The washing, blocking and rinsing procedures were repeated once more. Each well was then added with $100 \mu \mathrm{L}$ of rabbit anti-PE polyclonal antibody in $0.5 \%$ gelatin-PBS. The microplate was incubated at $37^{\circ} \mathrm{C}$ for $90 \mathrm{~min}$. The wells were washed again. Subsequently, $100 \mu \mathrm{L}$ of goat anti-rabbit IgG: alkaline phosphatase conjugated in 1:2000 dilution was added and allowed to react at $37^{\circ} \mathrm{C}$ for $90 \mathrm{~min}$. After another washing, $100 \mu \mathrm{L}$ of BluePhos Phosphatase Microwell substrate solution (KPL) was added and incubated at $37^{\circ} \mathrm{C}$ for $30 \mathrm{~min}$. Finally, $100 \mu \mathrm{L}$ of $2.5 \%$ EDTA was added to terminate the reaction. The absorbance at $650 \mathrm{~nm}$ was measured with a microplate reader. The average of six determinations was recorded.

\section{Statistical Analysis}

Statistical analysis was performed using SAS Statistical Software, Version 6.11 (SAS Institute). The difference between treatment means was analyzed using General Linear Model Procedure and Duncan's multiple range test. A $P$ value of $<0.05$ was considered statistically significant.

\section{RESULTS AND DISCUSSION}

\section{Purification of PE from Banana}

The activity of PE in banana pulp was found to be at maximum on the 16th day in a preliminary room temperature storage test (data not shown). Hence, the 
fully ripened bananas on the 16 days of storage were chosen for PE extraction. The SDS-PAGE diagrams of PE fractions with M.W. of 49.3-78.2 kDa indicated several isoforms as shown in Figure 1. The occurrence of PE isozymes was previously reported in hybrid aspen ${ }^{(4)}$, flax $^{(27)}$, and tomato ${ }^{(28)}$.

The molecular mass of banana PE in this study was higher than that of most plant PEs $(32-35 \mathrm{kDa})^{(29)}$. Goldberg et al. ${ }^{(30)}$ proposed that large molecule PEs, such as the neutral PE of mung bean hypocotyls (Vigna radiata) with a molecular mass of $45 \mathrm{kDa}$ and kiwi PE with a molecular mass of $57 \mathrm{kDa}^{(31)}$, be glycoproteins. Presum-

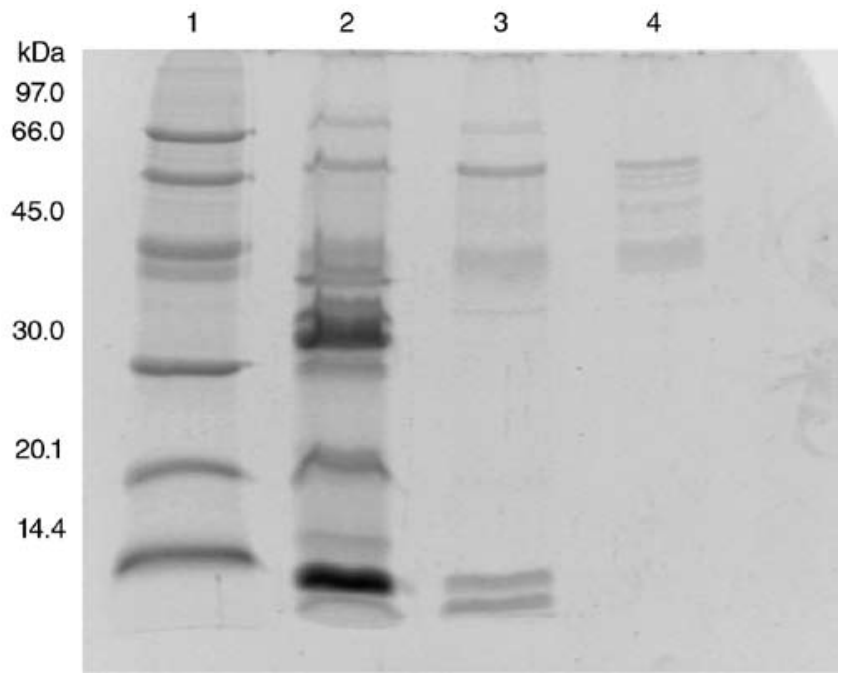

Figure 1. SDS-PAGE profiles of banana PE. (1) Molecular weight markers; (2) ammonium sulfate (30-70\% saturation) purified; (3) CM-Sepharose CL-6B chromatography purified; (4) Sephacryl S-200 HR chromatography purified. Polypeptides on the gel were stained with Coomassie brilliant blue.

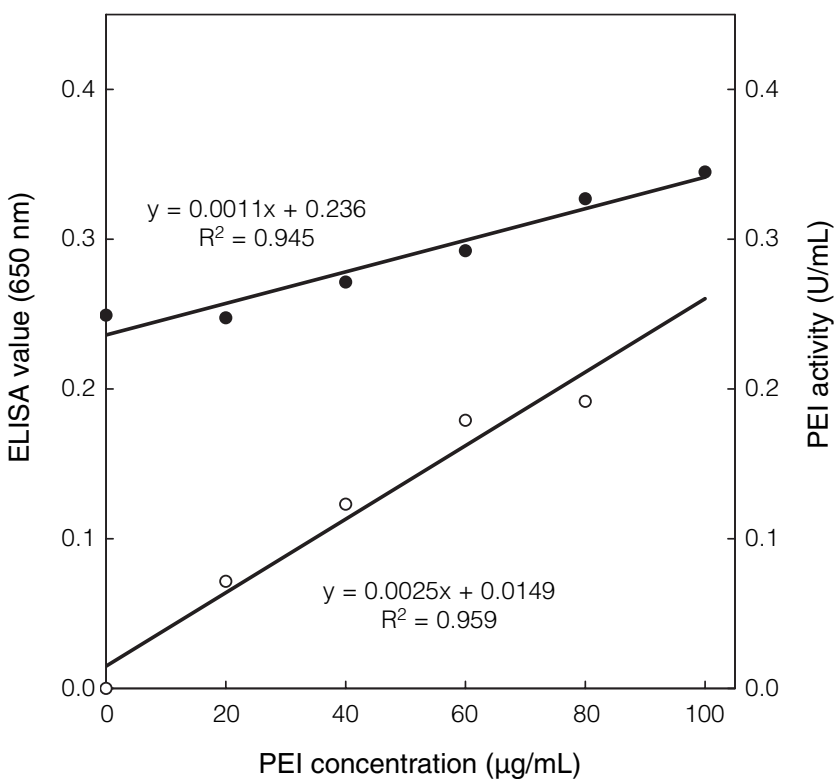

Figure 2. Determination of banana PEI by ELISA (-) and $\mathrm{pH}$-stat (O) methods. ably glycosylation occurs in banana too.

\section{Determination of PEI}

The determination of PEI in this study was made by traditional $\mathrm{pH}$-stat and the proposed ELISA method. As shown in Figure 2, there are good linear responses with the activity of banana PEI in both of the pH-stat $\left(\mathrm{R}^{2}=0.959\right)$ and the ELISA $\left(\mathrm{R}^{2}=0.945\right)$ methods. The responses to PEI activities in kiwi $\left(R^{2}=0.935\right)$ and jelly fig achenes $\left(\mathrm{R}^{2}=0.983\right)$ in PEI-ELISA method are also linear (Figure 3). The good correlation between PEI concentration and ELISA value and the successful determination of PEI in jelly fig (Ficus awkeotsang Makino) achene using anti-banana PE antibodies implied that PEI-ELISA method is suitable for PEI quantification. Our assumption was also proven that PE and PEI form a complex in a ratio of 1:1. The reported natural inhibitors of PE include the uncompetitive inhibitors sucrose ${ }^{(32)}$, KI and Na-dodecyl sulfate ${ }^{(12-13)}$, the competitive inhibitor polygalacturonic acid ${ }^{(33-34)}$, and PEI. The addition of the competitive inhibitor jelly fig PEI caused an increase of $\mathrm{K}_{\mathrm{M}}$ for PE-pectin reaction ${ }^{(16)}$. Therefore, to determine PEI by PEI-ELISA method that is based on the interaction between PEI and PE, is feasible even in the presence of other natural inhibitors of PE.

\section{Changes of PEI Activity in Postharvest Storage}

There was no significant difference $(p>0.05)$ in PEI activity within 16 days storage at $10^{\circ} \mathrm{C}$. However, the activity dropped significantly $(p<0.05)$ after switching to room temperature (Figure 4 ). The activity also dropped significantly $(p<0.05)$ after day 10 during storage at room temperature from the beginning (Figure 5).

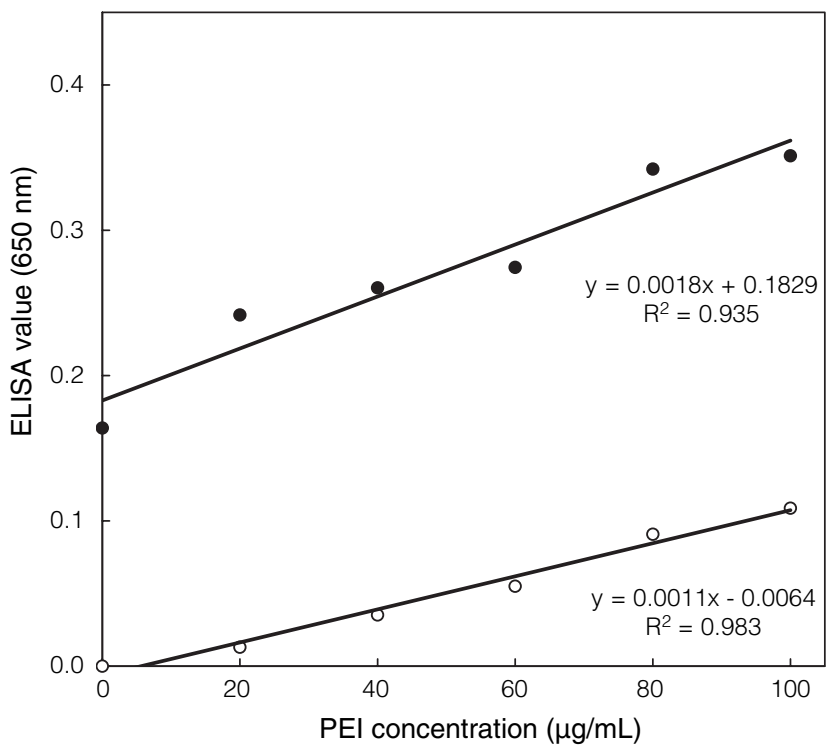

Figure 3. Determination of PEI from kiwi and jelly figachenes by ELISA method. 

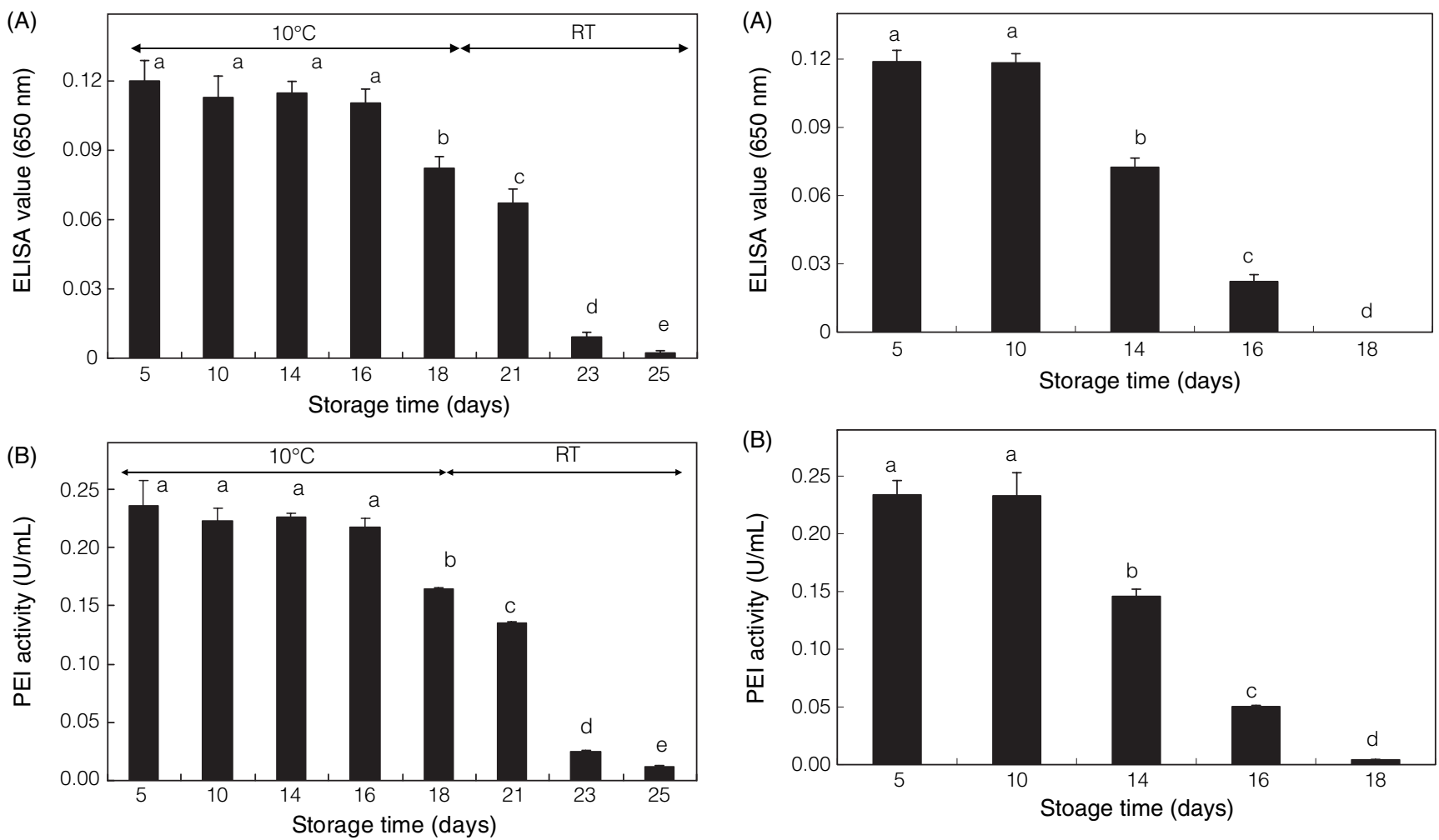

Figure 4. Changes in banana PEI analyzed by (A) ELISA and (B) $\mathrm{pH}$-stat methods during storage at $10^{\circ} \mathrm{C}$ for 18 days and at room temperature for another 7 days. Data bearing different superscript letters were significantly different $(p<0.05)$.

No significant difference $(p>0.05)$ was found when comparing the corresponding data of banana PEI activity determined by $\mathrm{pH}$-stat and PEI-ELISA methods in the above-mentioned storage tests.

Banana is highly susceptible to chilling injury ${ }^{(35)}$. Low temperature storage often results in pitting and discoloration of the peel and abnormal ripening of the pulp. Pulp softness, sweetness and flavor of modified atmosphere packed banana were found to be better than the fruit stored at $10^{\circ} \mathrm{C}$ for 12 or 18 days and then ripened at room temperature $\left(28^{\circ} \mathrm{C}\right)$ for 4 days ${ }^{(36)}$. The puncture force of banana was decreased in the order of $10,16,22$ and $28^{\circ} \mathrm{C}$ of storage ${ }^{(37)}$. Pathak and Sanwal ${ }^{(38)}$ and Marín-Rodríguez et al. ${ }^{(39)}$ proposed that PEI might play an important role in banana pulp softness caused by pectic enzymes and delay the ripening of banana fruits, especially at low temperature. Our experiments confirmed that the retardation in the ripening of banana pulp in low temperature storage is relevant to the maintenance of PEI activity.

\section{CONCLUSIONS}

ELISA is generally regarded as a precise analytical method with great specificity. The use of ELISA involving a polyclonal antibody against banana PE to quantify

Figure 5. Changes in banana PEI analyzed by (A) ELISA and (B) $\mathrm{pH}$-stat methods during storage at room temperature for 18 days. Data bearing different superscript letters were significantly different $(p<0.05)$.

the PEI in jelly fig achenes, kiwi fruit and banana pulp is proven successful. PEI-ELISA method has the advantage to avoid the interference from the buffer components in the sample and the alkali added in the conventional $\mathrm{pH}$-state PE inhibition assay. In the present study much more PEI is needed in the $\mathrm{pH}$-state method than in the ELISA method. The ELISA method is more sensitive than the $\mathrm{pH}$-state method, thus saving raw material and the effort in the preparation samples.

\section{ACKNOWLEDGEMENTS}

Financial support from the National Science Council of the Republic of China under Grant NSC 94-2313-B-266-002 is greatly appreciated. We would like to express our deepest regret that Dr. Hung-Min Chang had left us due to an accident. We also appreciate very much his devoted guidance in this study. Dr. Chang will always be remembered by his colleagues.

\section{REFERENCES}

1. Lee, C. W., Wu, M. C., Lee, B. H., Jiang, C. M. and Chang, H. M. 2003. Changes in molecular weight of transacylated pectin catalyzed by tomato and citrus pec- 
tinesterases as determined by gel permeation chromatography. J. Agric. Food Chem. 51: 5455-5461.

2. De Lorenzo, G., Castoria, R., Bellincampi, D. and Cervone, F. 1997. Fungal invasion enzymes and their inhibition. In "The Mycota. V. Plant Relationships, Part B". pp 61-83. Carroll, G. C. and Tudzynski, P. eds. Springer-Verlag. Berlin.

3. Lievens, S., Goormachtig, S., Herman, S. and Holsters, M. 2002. Patterns of pectin methylesterase transcripts in developing stem nodules of Sesbania rostrata. Mol. Plant Microbe Interact. 15: 164-168.

4. Micheli, F., Sundberg, B., Goldberg, R. and Richard, L. 2000. Radial distribution pattern of pectin methylesterases across the cambial region of hybrid aspen at activity and dormancy. Plant Physiol. 124: 191-199.

5. Micheli, F. 2001. Pectin methylesterases: cell wall enzymes with important roles in plant physiology. Trends Plant Sci. 6: 414-419.

6. Pilling, J., Willmitzer, L. and Fisahn, J. 2000. Expression of a Petunia inflata pectin methyl esterase in Solanum tuberosum L. enhances stem elongation and modifies cation distribution. Planta 210: 391-399.

7. Pilling, J., Willmitzer, L., Bucking, H. and Fisahn, J. 2004. Inhibition of a ubiquitously expressed pectin methyl esterase in Solanum tuberosum L. affects plant growth, leaf growth polarity, and ion partitioning. Planta 219: 32-40.

8. Tieman, D. M. and Handa, A. K. 1994. Reduction in pectin methylesterase activity modifies tissue integrity and cation levels in ripening tomato (Lycopersicon esculentum Mill.) fruits. Plant Physiol. 106: 429-436.

9. Wen, F. S., Zhu, Y. M. and Hawes, M. C. 1999. Effect of pectin methylesterase gene expression on pea root development. Plant Cell 11: 1129-1140.

10. Chen, M. H. and Citovsky, V. 2003. Systemic movement of a tobamo virus requires host cell pectin methylesterase. Plant J. 35: 386-392.

11. Dorokhov, Y. L., Makinen, K., Frolova, O. Y., Merits, A., Saarinen, J., Kalkkinen, N., Atabekov, J.G. and Saarma, M. 1999. A novel function for a ubiquitous plant enzyme pectin methylesterase: the host-cell receptor for the tobacco mosaic virus movement protein. FEBS Lett. 461: 223-228.

12. Jiang, C. M., Lai, Y. J., Chang, W. H., Wu, M. C. and Chang, H. M. 2001. Pectinesterase inhibitor in jelly fig (Ficus awkeotsang Makino) achenes. J. Food Sci. 66: 225-228.

13. Zimmerman, R. E. 1978. A rapid assay for pectinesterase activity which can be used as a prescreen for pectinesterase inhibitors. Anal. Biochem. 85: 219-223.

14. McMillan, G. P. and Pérombelon, M. C. M. 1995. Purification and characterization of a high $\mathrm{pI}$ pectin methylesterase isozyme and its inhibitor from tubers of Solanum tuberosum subsp. tuberosum cv. Katahdin. Physiol. Mol. Plant Pathol. 46: 413-427.

15. Balestrieri, C., Castaldo, D., Giovane, A., Quagliuolo, L. and Servillo, L. 1990. A glycoprotein inhibitor of pectin methylesterase in kiwi fruit (Actinidia chinensis). Eur. J. Biochem. 193: 183-187.

16. Jiang, C. M., Li, C. P., Chang, J. C. and Chang, H. M. 2002. Characterization of pectinesterase inhibitor in jelly fig (Ficus awkeotsang Makino) achenes. J. Agric. Food Chem. 50: 4890-4894.

17. Wu, M. C., Tseng, K. C., Huang, T. H. and Chang, H. M. 2002. Pectinesterase inhibitor in rubbery banana (Musa sapientum L.). J. Food Sci. 67: 1337-1340.

18. Castaldo, D., Lovoi, A., Quagliuolo, L., Servillo, L., Balestrieri C. and Giovane, A. 1991. Orange juices and concentrates stabilization by a proteic inhibitor of pectin methylesterase. J. Food Sci. 56: 1632-1634.

19. Jiang, C. M., Li, C. P. and Chang, H. M., 2002. Influence of pectinesterase inhibitor from jelly fig (Ficus awkeotsang Makino) achenes on pectinesterases and cloud loss of fruit juices. J. Food Sci. 67: 30633068.

20. Wu, J. S. B., Wu, M. C., Jiang, C. M., Hwang, Y. P., Shen, S. C. and Chang, H. M. 2005. Pectinesterase inhibitor from jelly-fig (Ficus awkeotsang Makino) achenes reduces methanol content in carambola wine. J. Agric. Food Chem. 53: 9506-9511.

21. Chang, J. H., Wang, Y. T. and Chang, H. M. 2005. Pectinesterase inhibitor from jelly fig (Ficus awkeotsang Makino) achene induces apoptosis of human leukemic U937 Cells. Ann. N. Y. Acad. Sci. 1042: 506-515.

22. D’Avino, R., Camardella, L., Christensen, T. M. I. E., Giovane, A. and Servillo, L. 2003. Tomato pectin methylesterase: modeling, fluorescence, and inhibitor interaction studies - Comparison with the bacterial (Erwinia chrysanthemi) enzyme. Proteins 53: 830-839.

23. Di Matteo, A., Giovane, A., Raiola, A., Camardella, L., Bonivento, D., De Lorenzo, G., Cervone, F., Bellincampi, D. and Tsernoglou, D. 2005. Structural basis for the interaction between pectin methylesterase and a specific inhibitor protein. Plant Cell 17: 849-858.

24. Giovane, A., Balestrieri, C., Quagliuolo, L., Castaldo, D. and Servillo, L. 1995. A glycoprotein inhibitor of pectin methylesterase in kiwi fruit: Purification by affinity-chromatography and evidence of a ripeningrelated precursor. Eur. J. Biochem. 233: 926-929.

25. Tsai, G. J. and Cousin, M. A. 1990. Enzyme-linked immunosorbent assay for detection of molds in cheese and yogurt. J. Dairy Sci. 73: 3366-3378.

26. Buchta, R. 1991. Ovine lactoferrin: isolation from colostrum and characterization. J. Dairy Res. 58: 211218.

27. Al-Qsous, S., Carpentier, E., Klein-Eude, D., Burel, C., Mareck, A., Dauchel, H., Gomord, V. and Balange, A. P. 2004. Identification and isolation of a pectin methylesterase isoform that could be involved in flax cell wall stiffening. Planta 219: 369-378.

28. Giovane, A., Quagliuolo, L., Servillo, L., Balestrieri, C., Laratta, B. and Castaldo, D. 1994. Purification and characterization of three isozymes of pectin methylesterase from tomato fruit. J. Food Biochem. 17: 339-349. 
29. Ciardiello, M. A., Tamburrini, M., Tuppo, L., Carratore, V., Giovane, A., Mattei, B. and Camardella, L. 2004. Pectin methylesterase from kiwi and kaki fruits: purification, characterization, and role of $\mathrm{pH}$ in the enzyme regulation and interaction with the kiwi proteinaceous inhibitor. J. Agric. Food Chem. 52: 7700-7703.

30. Goldberg, R., Pierron, M., Bordenave, M., Breton, C., Morvan, C. and Du Penhoat, C. H. 2001. Control of Mung bean pectin methylesterase isoform activities. Influence of $\mathrm{pH}$ and carboxyl group distribution along the pectic chains. J. Biol. Chem. 276: 8841-8847.

31. Giovane, A., Quagliuolo, L., Castaldo, D., Servillo, L. and Balestrieri, C. 1990. Pectine methyl esterase from Actinidia chinensis fruits. Phytochemistry 29: 28212823.

32. Fayyaz, A., Asbi, B. A., Ghazali, H. M., Che-Man, Y. B. and Jinap, S. 1995. Kinetics of papaya pectinesterase. Food Chem. 53: 129-135.

33. Lee, M. and MacMillan, J. D. 1968. Mode of action of pectin enzymes. I. Purification and certain properties of tomato pectinesterase. Biochemistry 7: 4025-4030.

34. Lourenco, E. J. and Catutani, A. T. 1984. Purification and properties of pectinesterase from papaya. J. Sci. Food Agric. 35: 1120-1127.
35. Pantastico, E. B., Ali Azizan, M., Abdullah, H., Acedo, A. L., Dasuki, I. M. and Kosiyachinda, S. 1990. Physiological disorders of banana fruit. In "Banana: Fruit Development, Postharvest Physiology, Handling and Marketing in ASEAN". pp. 85-103. Hassan, A. and Pantastico, E. B. eds. ASEAN Food Handling Bureau. Kuala Lumpur, Malaysia.

36. Nguyen, T. B. T., Ketsa, S. and van Doorn, W. G. 2004. Effect of modified atmosphere packaging on chillinginduced peel browning in banana. Postharvest Biol. Technol. 31: 313-317.

37. Chen, C. R. and Ramaswamy, H. S. 2002. Color and texture change kinetics in ripening bananas. Lebensm.Wiss. u.-Technol. 35: 415-419.

38. Pathak, N. and Sanwal, G. G. 1998. Multiple forms of polygalacturonase from banana fruits. Phytochemistry 48: 249-255.

39. Marín-Rodríguez, M. C., Smith, D. L., Manning, K., Orchard, J. and Seymour, G. B. 2003. Pectate lyase gene expression and enzyme activity in ripening banana fruit. Plant Mol. Biol. 51: 851-857. 